every clime. For with the Hippopotamus, the Rhinoceros, and the Lion from the south, we have also in abundance the Cyrcena fuminalis, a shell now characteristic of the Valley of the Nile and the rivers of India and China: whilst from the north advance to meet them the "MuskOx," the Reindeer, and the Lemming; we have also evidence at Walthamstow of the Elk (Alces malchis).

To Sir Antonio Brady, then, we are indebted for a most valuable collection of Pleistocene mammalia, now happily preserved in the British Museum of Natural History, Cromwell Road. Nor must we omit to mention that he strove by his presence, as a resident at Stratford, and by his constant acts of kindness and hospitality to the workmen, and by the largesse which he freely gave, to rescue from destruction these intere ting relics of a pre-historic age, which now help to swell the magnificent series of our National Museum.

HENRY WOODWARD

\section{BRIGHTON HEALTH CONGRESS}

THE Brighton Health Congress, which was opened on Tuesday, December I3, and which has been accompanied by an Exhibition of Domestic, Sanitary, and Scientific Appliances, has been one of the most successful of its kind, and by far the most successful of any of a purely local character. In origin and in progress it has, throughout, been Brightonian, and although many of the scholars who communicated addresses and papers were outsiders, they came by invitation. To the Congress in the course of the week no less number than rao added their names as Associates, while the Exhibition was at all times well filled, some 400 persons per day, independently of the Associates, paying for admission. It is estimated, indeed, that altogether between four and five thousand persons have been present. We stated last week that the Exhibition was presided over by Lord Chicliester, and the Congress by Dr. Richardson; and we gave a detail of the sections and order of proceedings: we shall dwell more particularly on the addresses and papers which were submitted.

\section{The President's Opening Address}

Dr. Richardson took for his theme "The Seed-Time of Health." In the opening passages he drew a picture of life and death in the time when the ancient Greeks were in the meridian of their intellectual existence. In the midst of the night, when the sun cannot see the deeds of men, certain of these were depicted carrying a dead child, in all its beauty, to the pyre. They carried it in this solemn silence and darkness because of the shame they felt that anything so young and beautiful should die in what ought to be the seed-time of health. Upon this he drew a sharp and striking contrast from our own time. He pointed out the great mortality of our children, for which we have grief, fond memories, but no shame. We accept the events, in short, as if they were natural, and erect memorials of them. After illustrating these points, the cruses of the great mortality of the young were classified under four heads-the inberited, the accidental, the inflicted, and the acquired. Under the first head the influence of hereditary diseases were discussed; under the second head the diseases of an epidemic character, and which occur from exposure to one or other of the communicable poisons, were considered; under the third head the injuries arising from bad nursing, excessive competition in education, and improper feeding, were brought under notice; and under the fourth head the evils incident to early resort to smoking, the use of stimulants, late hours, and irregular meals, were made subjects of comment. What now is wanted, said the President, was the ideal of a new nobility. In the wild-boar days of human existence; in days when men, hardly emancipated from lower forms of life, crept out of their caves, their huts, their walled prisons, to see their nobler species go forth to exercise those rude arts of hunting, fighting, revelling, which formed the whole art of civilisation, there was a nobility which deserved the name--the representative of necessity. But now, when these arts have degenerated into mere childish imitations, mere apedoms of the great past, they are but injurious pretensions for nobility of soul and body. Once noble, according to the spirit of their day they are in this day ignoble. The address concluded with two applications of thought, one general, the other local. The general requested those who rule and govern us to look at the seed-time of health as it is, and take it as the test of good or bad government. The local was addressed to the people of Brighton, that the meeting then commencing might be truly useful, and the date from whence they should move onwards until the shame of mortal events, which the sun should never witness, be felt whenever they occur.

\section{Section A.-Health of Towns}

The president, Mr. Edwin Chadwick, C.B., opened the Section on Wednesday with an address on the prevention of epidemics. He set out by describing the various means adopted to stay the great outbreak of cholera in I 848 , in which he took a prominent part, and the deductions made from observations then taken. The conclusions that had been come to then were that to aggregate disease in large hospitals was only to increase the danger, and that the very best means of preventing the spread of infection was by the adoption of sanitary measures at the places wbere, in the cycle of epidemics, they were to be expected. He described in a very interesting manner the precautions taken at York, at Mertbyr Tydvil, at Mevagissy in Cornwall, and other places, and the gradual decrease of deaths that followed, and he showed that similar precautions taken at St. Petersburg, Malta, and Memphis, had had the same result. At St. Petersburg, for example, the deaths had decreased from 25,000 to 3000 in the successive decade. Some other equally startling statistics were given by Mr. Chadwick. By the returns of the Local Government Board, he calculated that we had saved in the death-rate from disease or infection a quarter of a million of lives, and three million cases of sickness, and putting this at a money value, $5 l$. for death and $I l$. for a sickness, over four millions of money had been saved. In conclusion he portrayed with poetical picturesqueness a possible future "when medical science shall occupy itself rather with the prevention of maladies than their cure, when governments shall be induced to consider the preservation of a nation's health as important as the promotion of its commerce or the maintenance of its conquests, and when we may hope to see approach a time in which, after a life spent almost without sickness, we shall close the term of an unharassed existence by a peaceful Euthanasia."

The papers which followed the delivery of Mr. Chadwick's address were all of them good, and some of them of unusual excellence. Mr. Easton's account of the water supply of Brighton was exceedingly interesting and able. It led to a sharp and animated debate on the water softening process in large towns. Mr. Easton and the Mayor, while advocating the principle of softening water, seemed inclined rather to look upon it as a household than a municipal duty. They were opposed by several other speakers. Mr. Griffiths followed with a paper on the escape of foul gases from ventilating gratings on the main sewers of towns. The gist of his argument was that the faults were rather in the houses than in the sewers. If, he maintained, the sewer system of houses was so perfect that nothing could be retained in the sewer pipes, and if the houses were thoroughly cut off from the sewer, the risks of escape of gas were greatly reduced. What was wanted in the sewer was a current of air, not ventilation at one point. The defective house drainage 
throughout the country was the evil that required the most speedy rectification.

Dr. Mackay supplied an excellent paper on the geology and climate of Brighton in relation to health. He gave many details, and finally came to the conclusion that the general view was correct, that autumn was the best season for Brighton. The freshness and coolness of the town in the early summer ought also to be remembered.

Dr. Fussell pleaded the necessity for recreation spaces in all large towns. He said there were about 100 towns in England containing upwards of 25,000 inhabitants, and that much of the decrepitude and high mortality amongst the young was caused by the excessive density of the populations.

Mr. Ellice Clark dwelt on the anomalies in the administration of the sanitary laws; and Dr. Browning read paper on the correlation of public health and sanitary legislation.

One of the most interesting essays read in this section was by Mr. Frederick Walsh, and was entitled "Sanitation in Japan, a Comparative Study." Mr. Walsh, who has resided long in Japan, detailed the diseases most prevalent there, together with an account of the mode of application of the sewage for agricultural purposes. $\mathrm{He}$ condemned very strongly the system of London drainage, and argued against the loss which was sustained in consequence of that system, contending that we had created by it most of the evils of which we complain.

The last paper read in this section was by Mr. H. F. Lester, on "Reform in Slaughterhouses." The author described tersely the present condition of private slaughterhouses, and contended that the great reform required in them consisted in the erection of public abattoirs in all our large towns. The paper led to a brisk discussion, the general sentiment being in favour of the views expressed by the author. Owing to an accident of arrangement a paper by Mr. W. S. Mitchell, M.A., entitled "A Comparison of Énglish and Foreign Watering Places," had to be taken as read.

Section B-Food in Relation to National and Domestic Economy

The president, Mr. J. R. Hollond, M.A. M.P., opened the Section on Thursday with an address on the subject of the "Production, Distribution, and Economic Use of Food." In considering the first head, he maintained that until the conditions under which the land was held were modified, and a much larger portion of the land brought up to the level of the best farming, it was premature to speak of the limit to the production of bread and meat having been nearly reached. He noticed the obstacles to agriculture in our land customs and the imposition of extraordinary tithe on market and hop gardens. Our landed system hampered the nominal owner in his power of dealing with his land; our system of transfer stood in the way of a ready change of ownership, and the cultivator had insufficient security for the capital he put into his business. Under the second head he said Free Trade for us was not only a benefit, but a necessity, and commented upon the way in which the English food-producer was hampered by the heavy carrying-rates of the railway companies, and advocated the market system of Paris. In treating of the economic uses of food he advocated the use of vegetables in greater variety, and in regard to alcoholic drinks, from the point of view of making the most of the means at command, thought the outlay on them might with advantage be made elsewhere. In conclusion he alluded to the unsatisfactory results of our cooking arrangements and the wastefulness entailed thereby. He expressed himself in favour of teaching cookery in schools in a systematic way.

Dr. C. B. Drysdale then read a paper on "Cheap Food and Longevity," and showed by the statistics of New Zealand that, while the other circumstances were not specially favourable, as against this country, there was a lower death-rate, calculated at I 2 in Iooo annually, combined with great cheapness of food. He contended also that the comparative scarcity of food here was caused by the higher birth-rate, which should be publicly discouraged in all European states.

Mr. A. F. Halcombe read a paper of special excellence on "New Zealand as a Source of Food Supply," showing the great capacity of New Zealand for furnishing us with food, and the prospects ultimately of large supplies being obtained from this growing colony. The writer supported also the statements made by Dr. Drysdale as to the healthiness of the New Zealand Climate.

Miss Yates followed with a paper on Bread Reform. She especially recommended the use of wheatmeal bread. She urged the members to support this movement for the sake of the children who are ill-nourished from being fed on impoverished white bread.

Mr. T. B. Lightfoot, in a very lucid paper on the "Preservation of Food by Cold," detailed the various steps of the dry-air freezing process, and stated that there need be no further difficulty in supplying the demands of this country with wholesome fresh animal food if the matter be approached in a scientific and business-like spirit. His paper elicited from the President of the Congress the fact that he (the President) had seen the carcases unpacked from Australia, had examined the preserved flesh, had partaken of it, and had come to the conclusion that the scientific difficulties were solved, and that nothing but commercial cupidity at home stood in the way of abundant supply of cheap food for the working classes.

A paper by Mr. Wynter Blyth, on "Rational Feeding and Eclectic Dietetics" ; another paper by Dr. Whittle, on "Artificial Dieting of Infants"; another by Mr. Cowan, "On Honey as an Article of Food"; and still another by Mr. Mitchell, on "Lessons on Foods," led up to a final address by Major Hallett, on "Food-Plant Improvement." In this paper Major Hallett described his remarkable experiments and successes in improving the growth of wheat and other cereals, together with his latest experiments upon the growth of the cotton-plant, all of which we must reserve for another and special occasion.

Evening Lecture-Propagation of Disease through Food and Drink, by R. P. B. Taafe, M.D., Medical Officer of Health for Brighton

Dr. Taafe's lecture was a very carefully prepared reading on the diseases of the body which are propagated through food and drink. He dealt first with the introduction of parasitic diseases in this way, next of the zymotic. $\mathrm{He}$ presented in a very clear manner the views of those who support what is called, commonly, the germ theory of disease. Finally he dwelt upon the subject of prevention, and at the conclusion of his lecture received a very hearty wote of than'ss.

\section{Section C-Domestic Health, including Educational Training}

Dr. Alfred Carpenter on Friday delivered the presidential address on "Domestic Health." He dwelt upon the public indifference in regard to matters of health, and expressed his belief that there was a border-line between health and disease, in which the conditions necessary for the establishment of disease must have time to produce their results before the disease actually arose. Speaking of zymotic diseases, he urged that their very existence was an evidence that natural waste was retained somewhere in too close a proximity to particular persons who became subject to disease. He dealt with the error of sending wastes into sewers, and proceeded to show that these wastes as soon as they became such, changed their character unless properly and naturally dealt with by being given to the earth. The address was very warmly received.

The papers that followed were so numerous that 
although the section sat until nearly six o'clock they could not all be read.

The first by the late Sir Antonio Brady on "Prevention of Smoke in Fire Places" was read by Gen. Alexander, one of the secretaries of this section.

Mr. H. H. Collins followed on "Home Sanitation and House Inspection," the practical common sense of which was that every man and woman should be their own sanitary inspector.

Mr. Burton, for Prof. Fleeming Jenkin, argued the importance of associations with an annual subscription, for sanitary inspection.

Dr. Strong, of Croydon, supplied various hints on domestic sanitation, supporting earnestly a constant instead of an intermittent water supply. Mr. Bailey Denton treated on the subject of the domestic filtration of water, giving a description of the common filters in use, with special reference to those in the exhibition. Mrs. King created a great interest by an essay on "Health in Relation to Clothing," in which she proposed a radical change for the better in the clothing of women. Mr. Alderman Hallett, Mayor of Brighton, described an every-day process for the domestic softening of water from the chalk, and illustrated his paper by one or two simple and very neat experiments.

Mr. Henry C. Stephens took up the subject of public elementary education in relation to public health, presenting an exceedingly thoughtful and practical communication, in which it was urged that in the beginning of life the senses should be more carefully trained by easy exercise of observation, analysis of impression, and muscular training in connection with mental effort.

The proceedings of the section were brought to a close by an address singularly felicitous in style and matter, by Major Robert Edis, F.S.A., on "Sanitation in Decoration."

\section{General Meeting}

At the conclusion of the sectional sitting which, like all the others, had been held in the Dome, the President took the chair for the general meeting, at which the usual formal votes of thanks were moved, seconded, and carried, together with the following resolution of condolence and sympathy: "That this meeting has heard with the deepest regret of the death of their much esteemed and distinguished colleague, the late Sir Antonio Brady, and hereby requests the President of the Congress to convey to Lady Brady and her family the sincere condolence of the members in an event which to them and the public is so great a bereavement." After the general meeting a large number of the Associates attended the "Health Congress Dinner" in the Banqueting Room of the Royal Pavilion.

\section{Lecture to the Working Classes, by Brudenell Carter, F.R.C.S}

The proceedings of the Congress were brought to a fitting close on Saturday evening, Dec. 17, by the lecture delivered to the working classes, as well as to the Associates, by Mr. Brudenell Carter. The lecturer took for his topic "Eyesight," and for an hour and ten minutes held the large audience in closest attention. He first treated on the evolution of the eye as an optical instrument; next he described the structures of which the instrument is composed ; thirdly, he discussed the irregularities of structure, dealing specially with the two irregularities, short sight and colour-blindness; lastly, he treated on the practical application of the knowledge of visual defects in its relation to educational training. The bad practice of teaching children to read and write with their eyes close to the paper, by which the defect of short-sightedness is so extensively produced, was strongly condemned, as well as the faults connected with bad light, bad paper, and irregular and imperfect printing.

\section{The Exhibition}

We should be remiss if we did not add a few lines on the Exhibition. The managers of this department struck out quite a new line in making it something more than sanitary. They called it a domestic, sanitary, and scientific exhibition, and this enabled them to introduce various things that add to the useful and the ornamental, as well as the healthful. All kinds of electrical apparatus that could serve in the house were shown. Various kinds of mechanical contrivances, and numerous objects for illustrating artistic improvements, such as painting of walls in corridors, halls, staircases, and rooms. Horological instruments found a place, and a great number of instruments for recording time were under constant inspection. In addition, the bicyclists and tricyclists had their department, and were presented with a goodly show of these new machines for pleasurable and useful exercise. In a word, all was so excellently classified, selected, and arranged that on the whole we never remember to have seen so good an exhibition. In the six visits we made to it we cannot express correctly which pleased us most, the place itself and its exhibits, or the extraordinary interest with which all the visitors, rich and poor alike, took in it. Everybody seemed to show an intelligent desire to collect all practical information that could be obtained; and when from this task they passed to the fine art Loan Collection which the authorities at South Kensington had the kindness and excellent taste to supply, the transition from the useful to the beautiful was indeed a pleasurable sight.

The peculiar feature of the Brighton Health Congress was its character as an example. In numbers and importance of papers read and discussed it rivalled some of the organised congresses, which having the metropolis as their centre, proceed to different towns and make them for a short season their platform. There can be no doubt that there is some danger to what are called the peripatetic societies in this initiation. If the town of Brighton can call together twelve hundred members to a congress, secure papers for various important sections, command the services of efficient officers, issue a volume of Transactions, and get together a scientific exhibition that shall attract several thousands of visitors, what may not larger towns accomplish, such as Birmingham, Manchester, Leeds, Newcastle, Liverpool, Edinburgh, and Glasgow. These immense places cannot possibly be expected to remain uninfluenced by the example set by Brighton and the results of the example. If then each town takes to forming its own congresses, there will soon be little ground left for congresses on the visit. Towns will vie with towns in organising instead of receiving meetings organised for them to receive. For our part, however, we augur nothing but good from such a new departure and new development. The light of science and knowledge will only burn all the brighter in a place out of which it has been struck; and as every town must invite to its congresses the same workers as would go if they followed the peripatetics, the characters of the different meetings will be the same in effect and usefulness.

\section{ANCIENT TIDAL ACTION AND PLANES OF} MARINE DENUDATION

THERE is at least one question in ancient physical geology on which the speculations of Prof. R. S. Ball (NATURE, vol. xxv. pp. 79, 103) regarding the magnitude of Tidal Waves in times past seem to throw fresh light, namely, the origin of "planes of marine denudation." For those readers of NATURE who may not be familiar with this term, first proposed by Prof. Sir A. Ramsay, let me endeavour briefly to describe them. If we protract to a true scale the outlines of certain tracts of the British Isles, of Europe, or of America, we shall find 